\title{
ORÇAMENTO IMPOSITIVO É AVANÇO PARA ADMINISTRAÇÃO
}

Coluna publicada em 7.5.2013: <http://www.conjur.com.br/2013-mai-07/ contas-vista-orcamento-impositivo-avanco-administracao $>$

As declarações do presidente da Câmara dos Deputados, Henrique Eduardo Alves (PMDB-RN), ${ }^{1}$ ao manifestar intenção em acelerar a tramitação da Proposta de Emenda Constitucional 565/2006, que altera e acrescenta artigos da Constituição com a finalidade de tornar obrigatória a execução de dotações orçamentárias, traz de volta o debate sobre o "orçamento impositivo".

Trata-se de questão antiga, já de há muito objeto de discussões intensas, e de fundamental importância para a democracia, o equilíbrio e independência de poderes e até mesmo a autonomia dos entes federados, mas sobre a qual não há consenso entre os estudiosos do Direito Financeiro.

Não obstante ser um tema complexo, que dá margem a longas discussões, objeto de vários trabalhos que o abordam com profundidade, não posso deixar de aproveitar a oportunidade para, ainda que de modo sucinto e simplificado, abordar o tema e fazer algumas considerações para que se possa compreendê-lo.

A lei orçamentária tem características peculiares que a diferem substancialmente das demais leis. Tem natureza temporária - vale por um exercício financeiro, segundo a legislação vigente hoje no Brasil - e, ao definir a atividade financeira, cada ente federado, por esse período, depende, no âmbito das receitas, de previsões $\mathrm{da}$ arrecadação de recursos a se concretizarem futuramente. No que toca às despesas, aloca recursos para gastos cuja realização depende, muitas vezes, de uma série de fatores nem sempre controláveis e previsíveis.

1 Veja-se artigo Orçamento respeitosamente impositivo. Folha de S.Paulo, 14.4.2013, seção Tendências/Debates, p. A3. 
Vê-se, pois, que é lei cujo cumprimento não é possível exigir com o rigor que se espera das demais normas que compóem o ordenamento jurídico.

Daí surgirem divergências quanto ao caráter "mandatório" dos dispositivos da lei orçamentária, especialmente no que tange às despesas. Seriam meras "autorizações" para gastar, sem que houvesse obrigação de efetivar o gasto ("orçamento autorizativo"), ou teriam caráter "impositivo", de modo que, havendo previsão na lei orçamentária, o governante deve cumpri-la, efetuando o gasto de modo a dar cumprimento às açôes governamentais em cujas dotaçôes estão alocados os recursos ("orçamento impositivo")?

Trata-se de questão a exigir, evidentemente, um estudo minucioso do tema, o que não é compatível com estas breves palavras. ${ }^{2}$

Mas não impede que se possa contextualizá-la em função das discussões sobre a mencionada PEC, esclarecendo as relevantes consequências.

É possível adiantar, desde logo, que qualquer posição que venha um dia a se consolidar em torno do tema seguramente não poderá ocupar nenhum dos extremos. Ou seja, não se pode conceber que o orçamento seja uma lei apenas no aspecto formal, com dispositivos dotados de caráter meramente autorizativo, sob pena de torná-lo um instrumento inócuo para o planejamento e gestão governamentais, além de mitigar a importância de todo o processo legislativo, especialmente a participação do Congresso em sua discussão e aprovação. E também não é possível reconhecer em seus dispositivos um caráter mandatório de tal forma rígido e preciso que se permita assegurar a execução integral de todos os programas para os quais foram consignadas dotações, uma vez que inúmeros fatores, imprevisíveis e insuscetíveis de controle podem tornar isso impossível, inviável ou até mesmo não oportuno.

É imperioso constatar que a eficácia, a credibilidade e o respeito à lei orçamentária exigem que, uma vez aprovada, sua execução deva pautar-se pela busca do fiel cumprimento de seus dispositivos.

Como já mencionei ao tratar do tema, o "papel do processo de execução do orçamento é cumprir, com a maior fidelidade possível, o orçamento aprovado, de modo que se façam apenas os ajustes necessários, no montante imprescindível para

2 E passa pela própria definição da natureza da lei orçamentária, com as possibilidades de considerá-la como tendo uma natureza de "lei formal", pois teria apenas as características de lei por seguir os procedimentos próprios do processo legislativo, "lei material”, ou seja, teria também o conteúdo próprio de lei, produzindo efeitos concretos, criando relações jurídicas, ou uma natureza sui generis. Mas não é o caso, nestas poucas linhas, de avançar nessa discussão - fica para uma próxima oportunidade. 
adequar a aplicação das receitas arrecadadas no atendimento às necessidades públicas, sempre tendo em vista o interesse da coletividade". Para que isso ocorra, são necessários instrumentos de flexibilidade, a serem utilizados de modo a "cumprir o que foi estabelecido pela lei orçamentária em seu aspecto essencial, para o que se faz necessário realizar ajustes nas previsões e programações orçamentárias durante o curso de sua execução", sendo necessário compatibilizar "a necessidade de cumprir-se fielmente o orçamento, do modo como aprovado pelo Poder Legislativo, com as imprescindíveis alterações que se fazem necessárias ao longo do exercício financeiro, sem, com isso, descaracterizá-lo e fazer dele uma peça de ficção".

Para isso, existem instrumentos como os créditos adicionais, por meio dos quais são aprovadas alterações na lei orçamentária; o contingenciamento, com o qual o Poder Executivo, gestor das finanças públicas e comandante do processo de execução orçamentária, adéqua e compatibiliza a entrada e saída de recursos, os remanejamentos são instrumentos, como os créditos adicionais e contingenciamentos.

São úteis e necessários para o processo de execução orçamentária, que, no entanto, devem ser utilizados com parcimônia, pois o abuso e falta de critérios podem fazer deles instrumentos que desviam a execução da lei orçamentária de seu curso, levando o orçamento executado a diferir substancialmente do que foi aprovado - e tornando-o, portanto, uma lei com pouco ou nenhum conteúdo material, incapaz de produzir os efeitos que lhe são próprios, como o de dar segurança jurídica ao sistema de planejamento governamental e gestão pública.

Mas não é o que se tem observado.

A frequência com a qual os Poderes Executivos de todas as esferas de governo abusam desses instrumentos, contingenciando dotações de modo a impedir que sejam executadas antes de findo o exercício, realocando recursos com base em margens de remanejamento pré-aprovadas e de forma excessiva, e utilizando-se de outras tantas manobras orçamentárias, está a exigir uma postura mais rigorosa por parte do Poder Legislativo, voltada a fazer com que a lei orçamentária venha a cumprir efetivamente seu papel constitucional, de condutora da atividade financeira do Estado.

E é nesse sentido que caminha a PEC em tramitação ora referida.

Das alterações propostas, destaca-se a inclusão de dispositivo que considera a programação constante da lei orçamentária de execução obrigatória, exigindo autorização prévia e expressa do Congresso Nacional para eventual cancelamento ou contingenciamento, parcial ou total, da dotação.

3 CONTI, José Mauricio. A autonomia financeira do Poder Judiciário. São Paulo: MP Editora, 2006, p. 107. 
Com isso, o Poder Executivo deixa de ter excessiva discricionariedade no uso desses instrumentos de flexibilidade orçamentária, que passarão doravante a ser submetidos à aprovação pelo Poder Legislativo, a quem caberá decidir sobre aspectos importantes do processo de execução do orçamento público. $\mathrm{O}$ orçamento passará a se tornar mais previsível e capaz de conferir maior segurança jurídica à administração pública e a todos que dela dependem e com ela se relacionem.

Além disso, impedirá o uso distorcido que tem sido feito desses instrumentos, como se vê quando o Poder Executivo obsta a liberação de recursos já consignados no orçamento com a finalidade de fazer deles "moeda de troca" para barganhas políticas diversas, aos quais já me referi em colunas anteriores, a cuja leitura remeto o leitor (veja-se, especialmente, Emendas ao orçamento e desequilíbrio de Poderes, publicada em 3 de julho de 2012, e Transferências voluntárias geram desequilíbrio federativo, publicada em 28 de agosto de 2012).

A PEC ora referida não tem a pretensão de tornar o orçamento rigorosamente impositivo (até porque isso nem seria possível, dadas as características próprias da lei orçamentária). Vê-se que os propósitos são bem menos ambiciosos do que esse, uma vez que, mesmo aprovada, ainda será insuficiente para assegurar que os programas de trabalho inseridos no orçamento sejam executados.

Ressalte-se ainda que, conforme declara o deputado Henrique Alves, parece haver intenção de restringir a obrigatoriedade da execução para as dotações orçamentárias decorrentes das emendas parlamentares, de modo a se fazer respeitar a decisão dos congressistas em relação à pouca colaboração que têm dado na elaboração do orçamento, com a aprovação de emendas contendo algumas indicações de gastos públicos pontuais e que, mesmo assim, não vêm sendo respeitadas pelo Poder Executivo.

Mas, independentemente das razões que a justificam e até do fato de os interesses que a sustentam terem dimensões menores do que a questão jurídica de fundo, o fato é que a aprovação dessa emenda constitucional promoverá um importante avanço no sentido de se fazer respeitar a lei orçamentária. Colaborará decisivamente para lhe conferir maior eficácia e credibilidade - o que já é uma evolução para o que se espera de um futuro próximo, que é a máxima "impositividade" do orçamento -, e contribuirá para o respeito à democracia, à vontade popular expressa por ocasiáo da aprovação da lei orçamentária, à independência e autonomia dos poderes e ao planejamento e gestão eficiente da administração pública, elementos essenciais para o desenvolvimento econômico e social. 